\title{
Females transplanted with ovaries subjected to hypoxic preconditioning show impair of ovarian function
}

\author{
Luciana Lamarão Damous ${ }^{1,4^{*}}$, Juliana Sanajotti Nakamuta ${ }^{2}$, José Maria Soares-Jr ${ }^{1}$, Gustavo Arantes Rosa Maciel ${ }^{1}$, \\ Ricardo dos Santos Simões ${ }^{1}$, Edna Frasson de Souza Montero ${ }^{3}$, José Eduardo Krieger ${ }^{2}$ and Edmund Chada Baracat ${ }^{1}$
}

\begin{abstract}
Background: Cryopreservation of the ovarian tissue has shown promising results. However, there remain controversial issues such as the short half-life of grafts. In this aspect, there are some evidences that preconditioning the ovarian tissue before transplantation is beneficial.

Objective: To determine the effect of hypoxic preconditioning in vitro on ovarian tissue prior to transplantation. Methods: Eighteen female adult Wistar rats, were sorted into three experimental groups. Ovaries were maintained in DMEM low glucose serum free at $37^{\circ} \mathrm{C}$ with $5 \% \mathrm{CO} 2$, at atmospheric oxigen concentration (normoxia) or $1 \% \mathrm{O}_{2}$ (hypoxia) for 16 hours. Oxigen concentration was determined by injection of nitrogen in the incubator. Animals submitted to ovarian transplantation immediately after oophorectomy were the Control Group (C). After this, the ovaries were implanted in the retroperitoneum with nonabsorbable suture and animals evaluated for thirty days after transplantation. Beginning on postoperative $(\mathrm{PO})$ day 11 , a daily collection of vaginal smear was carried out. Analyses comprised morphological, morphometric (counting ovarian follicles and corpora lutea) and immunohistochemistry for cleaved caspase-3 (apoptosis).
\end{abstract}

Results: In normoxia and control groups all animals recovered their estrous cycles, while in the hypoxia group, two animals did not ovulate but, among those which did, resumption took longer than in the other groups $(p<0.05)$. The number of ovarian follicles and corpora lutea decreased significantly in the hypoxia group when compared to the other two groups $(p<0.001)$ and apoptosis was increased in the few ovarian follicles which remained viable $(p<0.001)$.

Conclusion: The hypoxic preconditioning in vitro was not beneficial to the graft and worsened their viability, compromising its functionality or delaying the return of this.

Keywords: Ovarian transplantation, Hypoxic preconditioning, Apoptosis, Ovary, Rat

\section{Background}

Preservation of female fertility has become a main concern when evaluating first time patients at risk of becoming infertile or even sterile, especially in the case of children, adolescents and young women with cancer. This is necessarily a new challenge given the longer life expectancy of such

\footnotetext{
* Correspondence: lucianadamous@gmail.com

'Gynecology Division, Department of Obstetrics and Gynecology, Laboratory of Structural and Molecular Gynecology (LIM-58), Faculdade de Medicina da Universidade de São Paulo, São Paulo, Brazil

${ }^{4}$ Galvão Bueno St, 499. Bloco A. Apto31. Liberdade, São Paulo 01506-000, SP, Brazil

Full list of author information is available at the end of the article
}

patients as the direct result of advances in the diagnosis and treatment of the disease. Several assisted-reproduction techniques have been developed, the most recent of which is cryopreservation of ovarian tissue for subsequent transplantation [1-3].

Cryopreservation of the ovarian tissue has shown promising results. Besides not delaying the radiotherapy or chemotherapy treatment, for this technique can be carried out promptly, it is the only option available for children [1]. However, there remain a few controversial issues requiring experimental models for research on undesirable findings in patients who have undergone ovarian tissue

\section{Ciomed Central}

(c) 2014 Damous et al.; licensee BioMed Central Ltd. This is an Open Access article distributed under the terms of the Creative Commons Attribution License (http://creativecommons.org/licenses/by/2.0), which permits unrestricted use, distribution, and reproduction in any medium, provided the original work is properly credited. The Creative Commons Public Domain Dedication waiver (http://creativecommons.org/publicdomain/zero/1.0/) applies to the data made available in this article unless otherwise stated. 
transplantation, such as the comparatively short half-life of grafts, little responsiveness to hormone stimulation, and development of empty follicles [2-5].

Experimental studies of ovarian tissue transplantation generally exhibit a $50 \%$ to $90 \%$ reduction in follicle density [6,7], undesirable follicle activation (increase in the number of follicles) $[8,9]$, and asynchronous growth of oocytes and follicle cells [10].

There are some evidences that preconditioning the ovarian tissue before transplantation is also beneficial. In a study of xenotransplantation, Lan et al. [11] demonstrated that the 6-hour fetal ovary culture without hypoxia prior to transplantation improved graft viability and increased the proportion of primordial and preantral ovarian follicles. Previous studies of ours showed that ischemic preconditioning of the ovary improves graft quality $[12,13]$. This motivated us to research other preconditioning forms to determine whether they could also increase the viability and longevity of grafts.

In vitro hypoxia has shown a number of beneficial effects, including cell lesion reduction, increased Vascular Endothelial Growth Factor (VEGF) expression with a resultant boost in angiogenesis, reduction of oxidative stress in endothelial cells [14], and an extension of the life span of stem cells derived from adipose tissue [15]. Our study set out to determine the effect of in vitro hypoxia on ovarian tissue prior to transplantation not only for the before mentioned reason but with a view to improving ovarian morphology and diminishing the apoptosis of ovarian follicle cells.

\section{Methods}

Before being carried out, this project was submitted to the Ethics Committee, Department of Obstetrics and Gynecology and to the Committee for Analysis of Research Projects, University of São Paulo Medical School (CAPPesq-FMUSP - protocol 190/10). The project was carried out at the Medical Research Laboratory (LIM-58), Gynecology Discipline, Department of Obstetrics and Gynecology, FMUSP, with the cooperation of Laboratory Genetics and Molecular Cardiology, Heart Institute (Incor), FMUSP. The experimental procedures followed institutional guidelines for care and use of laboratory animals.

The study sample consisted of 18 virgin adult female Wistar (Rattus norvegicus albinus) rats weighing 200 to $250 \mathrm{~g}$. The animals had access to a breed-specific food formula and water ad libitum throughout the experiment and were kept under adequate sanitary, lighting, and temperature conditions in the animal laboratory at the Heart Institute (Incor).

The animals were allocated to three study groups of six animals each. The groups were formed according to the following procedures: (1) Control: ovarian transplant immediately after oophorectomy; (2) Normoxia: between oophorectomy and transplantation, the ovaries remained overnight $(16 \mathrm{~h})$ in DMEM low glucose serum free at $37^{\circ} \mathrm{C}$ with $5 \% \mathrm{CO}_{2}$, at atmospheric oxygen concentration $\left(21 \% \mathrm{O}_{2}\right)$; (3) Hypoxia: the ovaries remained overnight $(16 \mathrm{~h})$ in DMEM low glucose serum free at $37^{\circ} \mathrm{C}$ with $5 \% \mathrm{CO}_{2}$ and $1 \% \mathrm{O}_{2}$ before transplantation.

Before the surgical procedures, vaginal smears were obtained daily from each rat at 8:00-9:00 every morning. Only those showing at least two consecutive normal 4day vaginal estrus cycles were included in the experiment. The ovarian transplant was performed during the diestrous phase, and euthanasia during estrus.

The vaginal smear was obtained with a swab soaked in physiological solution and placed on a standard slide and immediately fixed in absolute alcohol for staining using the Shorr-Harris technique [16].

The slides were analyzed under a light microscope at 10x and 40x magnification. Based on the proportion of cells found in the smears, the estrous cycle phases were characterized as follows: (1) Proestrus, predominance of nucleated epithelial cells; (2) Estrus, predominance of anucleated, keratinized cells; (3) Diestrus, the same proportion of leukocytes and nucleated, keratinized epithelial cells [16].

The animals were anesthetized with intraperitoneally administered xylazine at a dose of $15 \mathrm{mg} \cdot \mathrm{kg}^{-1}$ of body weight and ketamine at a dose of $60 \mathrm{mg} \cdot \mathrm{kg}^{-1}$ of body weight. After the opening of the abdominopelvic cavity, the ovaries were identified; their pedicles were clamped and immediately ligated with 4-0 nylon suture. Next, the ovaries were removed bilaterally at the junction of the uterine horns and hemostasis was checked; the excised ovaries were then washed in physiological solution $(0.9 \% \mathrm{NaCl})$. Finally, the fallopian tubes were resected with the periovarian adipose tissue fragments.

Each animal received a pair of autologous ovary transplants. The procedure was carried out with the aid of a surgical microscope (16x). In the control group, the ovaries were transplanted immediately. In the normoxia and hypoxia groups, the ovaries were placed in low-glucose DMEM (Dulbecco's modified Eagle's medium) in P35 Petri dishes, which were then incubated at $37^{\circ} \mathrm{C}$ overnight $(16 \mathrm{~h})$ in previously programmed concentrations of $5 \%$ $\mathrm{CO}_{2}$ and $21 \% \mathrm{O}_{2}$ for the normoxia group and $5 \% \mathrm{CO}_{2}$ and $1 \% \mathrm{O}_{2}$ for the hypoxia group.

Afterwards, with a simple stitch of 4-0 nylon sutures, the intact ovaries were implanted in the retroperitoneum in the proximity of the great vessels (aorta and vena cava), each on one side of the psoas muscle, without vascular anastomosis. The wall closure was performed with a 5-0 nylon monofilament thread on two planes: (1) peritoneum - aponeurotic muscle and (2) skin.

Beginning on postoperative (PO) day 11, vaginal smears were obtained daily from each rat at 8:00-9:00 every 
morning until euthanasia, which was performed between day 30 and 35, with the rats always in estrus. The animals not in estrus during this period of time were excluded from the study.

The ovarian graft was removed and immediately fixed in $10 \%$ buffered formalin for $24 \mathrm{~h}$ for subsequent routine histological processing and hematoxylin-eosin staining. The ovarian cortex was sectioned into two pieces of equal size. After this procedure, the animals were euthanized with a lethal dose of the previously used anesthetics.

Morphological evaluation was achieved through descriptive analyses of the grafts. Assessment of follicular quality was based on cell density, the presence or absence of pyknotic bodies, and the integrity of the basement membrane and of the oocyte. According to these criteria, follicles were classified as normal or degenerated; only the former were characterized and quantified [17].

The viable follicles were classified as follows: (1) Primordial follicle, exhibiting only an oocyte and a layer of squamous cells; (2) Primary follicle, exhibiting an oocyte and a layer or more of cuboidal or prismatic cells but no antrum; (3) Secondary follicle, exhibiting an oocyte and an antrum. The mature follicle was that which contained an oocyte with a voluminous antrum. The corpus luteum was that which had intact luteal cells containing a voluminous nucleus and surrounded by capillary blood vessels $[9,18,19]$.

The mature follicles were analyzed morphometrically in a $500-\mu \mathrm{m}^{2}$ area [20]. To carry out the analysis, the follicles were classified into different stages forming three groups as follows: (1) developing follicles (primordial, primary, and preantral); (2) mature follicles (with only one voluminous antrum); (3) corpora lutea [18,21].

Images of the sections were obtained using an image acquisition software system (Leica DM2500); measurements were obtained using the Leica QWin V3 software. Counting was always done in four fields per section at $50 \times$ magnification.

Antibodies in the ovarian tissue were detected by the immunohistochemical-peroxidase method. Three- $\mu \mathrm{m}$ thick sections were cut on silanized slides and then the following protocol was put in place: (1) Hydration: the sections were dewaxed with hot xylol $\left(65^{\circ} \mathrm{C}\right)$ for $15 \mathrm{~min}$ and with cold xylol for another $15 \mathrm{~min}$, washed in $95 \%$ absolute alcohol, and hydrated in deionized running water; (2) Antigen recovery: the sections were exposed to high temperatures in a pressure cooker with citrate buffer (pH6) at $125^{\circ} \mathrm{C}$ for $1 \mathrm{~min}$; the sections were then washed in Phosphate Buffered Saline (PBS); (3) Blockage: endogenous peroxidase activity blocking was performed 10 times for 5 min each time with 3\% 10v hydrogen peroxide $\left(\mathrm{H}_{2} \mathrm{O}_{2}\right)$ and was followed by washing in water and PBS; (4) Incubation with the primary antibody: caspase-3 (caspase-3 p20 N-19:sc- 1226, Santa Cruz Biotechnology) (1:100 dilution) was diluted in BSA and applied on the sections and on the positive and negative tissue controls; the sections were then incubated overnight.

The sections were washed in PBS and incubated in the Novocastra Novolink Max (Polymer), RE7260-K, (Leica Microsystems, Wetzlar, Germany): both in the post primary block and in the polymer at room temperature for $30 \mathrm{~min}$ each. Subsequently, the sections were developed using the liquid 3,3'-diaminobenzidine (DAB) chromogen for $5 \mathrm{~min}$. Next, the sections were washed in abundant running water and counterstained with Harris' hematoxylin solution (Merck, Darmstadt, Germany). Immediately afterwards, they were washed in running water, dehydrated, cleared, and mounted using the resinbased mounting medium Entellan (Merck, Darmstadt, Germany).

Images of the sections were obtained using an image acquisition software system (Leica DM2500); measurements were obtained using the Leica QWin V3 software. Apoptosis assessment by means of caspase- 3 was undertaken always using the percentage of positive area in the ovarian follicles in 4 different fields per animal at 200x magnification. Positively stained follicle cells were quantified as the percentage of positive cells per area. Negative control has no primary antibody. Two independent investigators blinded to the experimental treatments performed all measurements.

Results were expressed as means \pm standard deviation of mean. One-way analysis of variance (ANOVA) with Tukey's post-hoc test was utilized to compare groups. All statistical analyses were performed using Graphpad Prism 4.0 (Graphpad software Inc, CA, USA). P values of $<0.05$ were considered significant.

\section{Results}

\section{Estrous cycle}

Analysis of the estrous cycle showed that all animals in the control and normoxia groups resumed regular

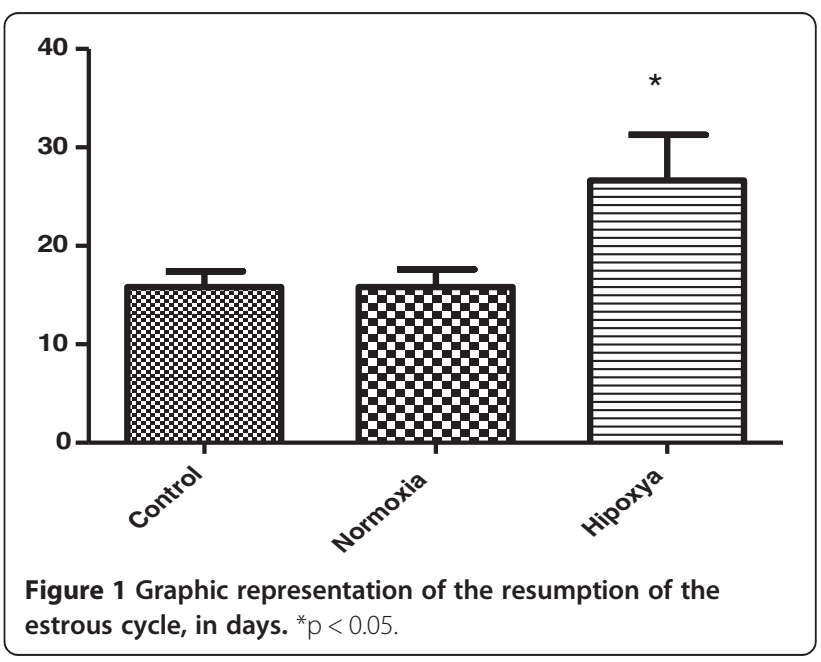




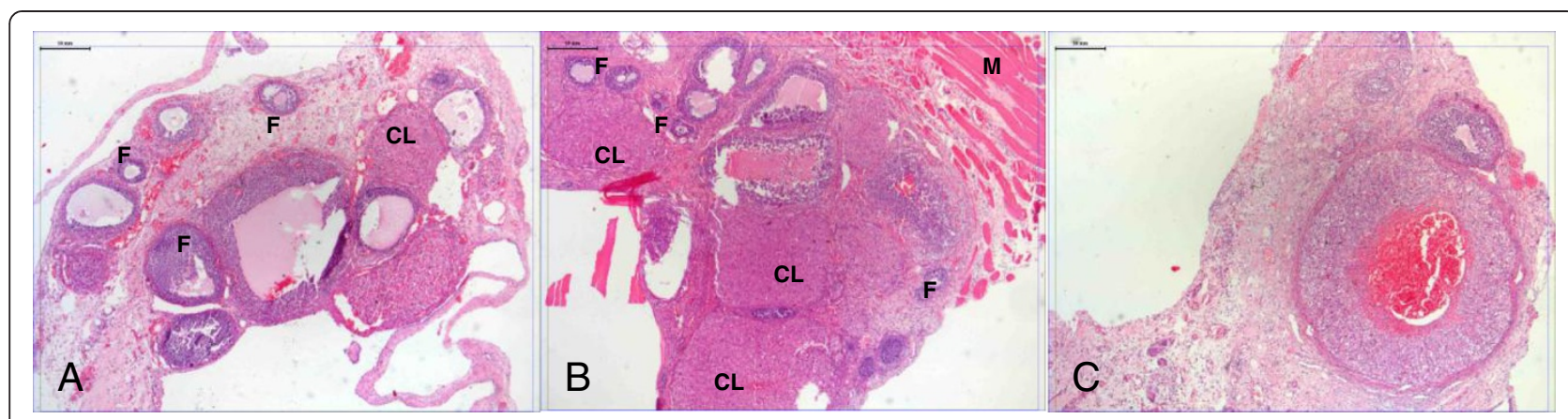

Figure 2 Photomicrography of the ovaries after 30 days of transplantation 50x. (A) Control Group; (B) Normoxia Group; (C) Hypoxia Group. $\mathrm{F}=$ Follicle; $\mathrm{CL}=$ Corpora Lutea; $\mathrm{M}=$ Muscle.

estrous cycles with estrus returning within an average of $15.8 \pm 3.63$ and $15.8 \pm 4.02$ postoperative days, respectively. In the hypoxia group, two animals did not ovulate, but, among those which did, resumption took longer than in the other groups, an average of $26.7 \pm 8.02$ postoperative days $(\mathrm{p}<0.05$; Figure 1$)$.

\section{Morphology}

Ovarian graft morphology of the control and normoxia groups revealed ovarian follicles in diverse developmental stages and corpora lutea in all of the animals which were assessed $(n=12)$. The grafts subjected to hypoxia showed engorgement of numberless blood vessels and atypical ovarian follicles. Some of these had a reduced number of follicle cell layers infiltrated by leukocytes, pointing to a degenerative process; others had a blood vessels among the follicle cells; and a few had no oocytes, forming cysts in the ovarian stroma. In the latter group, there was reduced number of corpora lutea, most of which exhibited cells with pycnotic nuclei and leukocyte infiltrate, indicative of cell degeneration $(n=6)$ (Figure 2).

\section{Morphometry}

The number of ovarian follicles and corpora lutea decreased significantly in the hypoxia group when compared to the other two groups $(\mathrm{p}<0.001)$. These showed no significant difference between them $(\mathrm{p}>0.05)$. Ovarian follicles: Control:9.2 \pm 2.58 ; Normoxia: $7 \pm 2.34$; Hypoxia: $0.8 \pm 0.83$. Corpora lutea: Control: $10.75 \pm 2.98$; Normoxia: $8 \pm 2$; Hypoxia: $1 \pm 1.22$ (Figure $3 \mathrm{~A}$ and $\mathrm{B}$ ).

\section{Immunohistochemistry}

Hypoxia prior to transplantation boosted cleaved caspase3 expression significantly in the few ovarian follicles which remained viable $(\mathrm{p}<0.001)$, whereas apoptosis was similar in the normoxia and control groups $(\mathrm{p}>0.05)$ (Control: $6.46 \pm 4.48$; Normoxia: $18.91 \pm 13.8$; Hypoxia: $82.13 \pm 39.96$ ) (Figures $3 \mathrm{C}$ and 4 ).

\section{Discussion}

Transplantation of the cryopreserved ovary still needs further experimental studies, despite the promising results in the human reproduction field. At present, there are reports of several cases of autologous ovary transplants in orthotopic sites enabling spontaneous pregnancies [3]. The first case of spontaneous pregnancy was reported by Donnez et al. [22]. However, there are many reports on failures, primarily having to do with the short life span of the graft and with the absence of pregnancy even under hormonal stimulation. What might justify such failures is ischemia and fibrosis, both of which follow a transplant and result in the loss of the

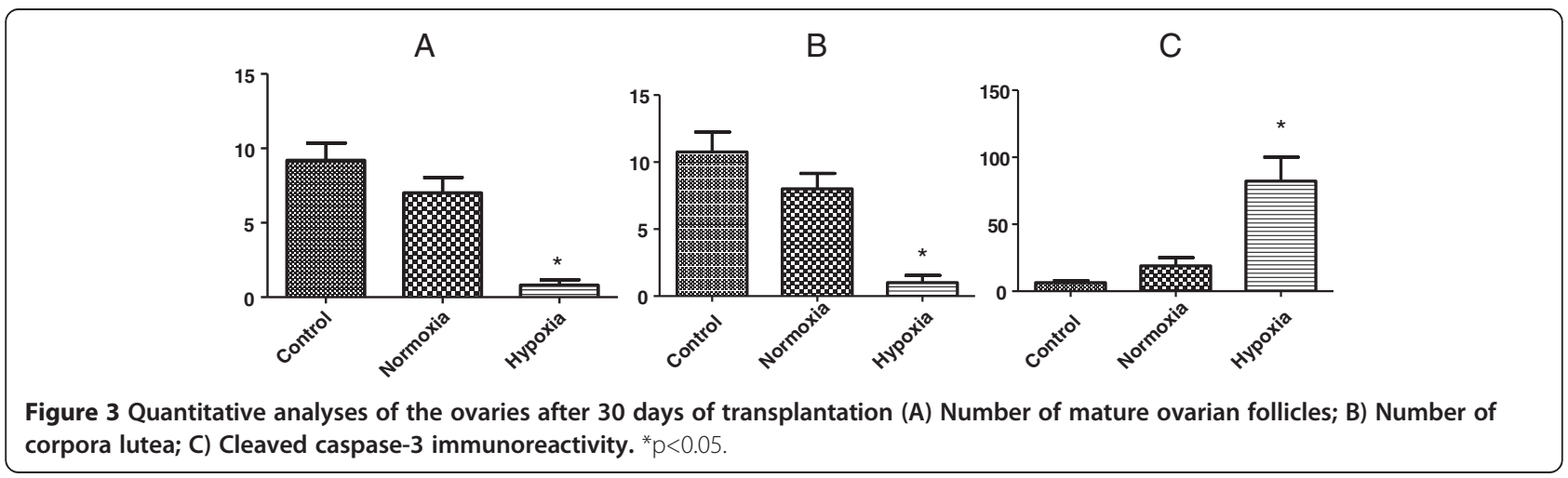




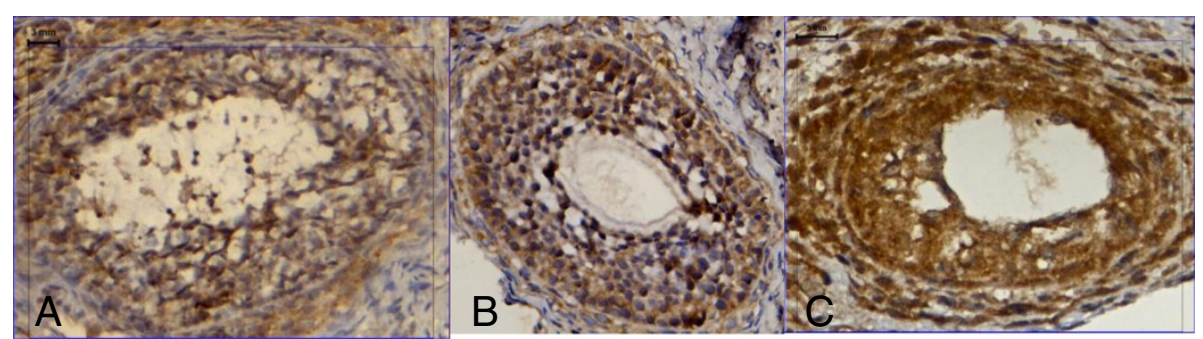

Figure 4 Photomicrography of cleaved-caspase-3 immunoreactivity. 400×. (A) Control Group; (B) Normoxia Group; (C) Hypoxia Group.

follicle population, preventing the recovery of fertility $[23,24]$. There are several experimental treatments for improving graft quality and one of the proposal is tissue cultivation [11].

Hypoxia preconditioning has yielded relevant results in the transplantation of other organs, such as the liver [25] and kidneys [26], and in cardiac regeneration after infarction [27]. In cell culture, hypoxia can increase proliferation rates and enhance differentiation along the different mesenchymal lineages [28]. Hypoxic preconditioning had a protective effect against mesenchymal stem cell apoptosis induced by hypoxia and reoxygenation via stabilization of mitochondrial membrane potential and upregulation of Bcl-2 and VEGF [29]. However, our results did not show any improvement in transplantation when the ovary was previously subjected to in vitro hypoxia.

Our study was based on the assumption that an in vitro hypoxia preconditioned ovary would respond better than an ovary exposed to hypoxia following transplantation, because it would have released environmental growth factors and free radicals, thus inducing early neoangiogenesis [30-33], which is crucial for preservation of the follicle pool. Our data, however, showed that overnight in vitro hypoxia before transplantation compromised graft viability with pronounced reduction in the number of viable ovarian follicles and functional corpora lutea.

The overall results were corroborated by cytological analysis of the vaginal smears, which showed a delayed resumption of the estrous cycle in the animals subjected to hypoxia as well as in those which remained in anestrus throughout the observation period (30-35 postoperative days). The option for cytology of vaginal smears was based on its great replicability. Other methods, such as hormone measurements, which are subject to variations induced by natural animal diversity or by environmental stress or handling, could have led to inconclusive results.

Lan et al. [11] were the first to assess the impact of in vitro ovary culture on follicle viability and development as well as the ideal length of culture time prior to xenotransplantation ( $0,3,6$ or 9 days). The authors observed an increase in mature follicles in the ovaries that remained for 6 days in culture in a standard oven. This is the reason we chose this treatment in our study.

Several experimental hypoxia models for investigating pathophysiology or for testing different therapeutic strategies are described in the literature, both in vivo (liver) [34] and in vitro (cerebral cortex [35] and cardiac cells [36]). Wang et al. [36] investigated adult rat cardiac microvascular endothelial cells and Merino et al. [35] cortical neurons, both using $94 \% \mathrm{~N}_{2} / 5 \% \mathrm{CO}_{2} / 1 \% \mathrm{O}_{2}$. In this study, in order to induce hypoxia, we used the same gradient described in studies of other tissues [35-37], since we did not find any reports on in vitro hypoxia models for the ovary. However, the condition of severe hypoxia induced harmful changes in the graft, compromising its functional return. Further studies may help to clarify whether other oxygen concentrations (5\% or $10 \%$ ), as well as different hypoxia times, may produce a beneficial effect. We tested the $16 \mathrm{~h}$-period, but smaller or even intermittent periods of time using the same gradient $\left(1 \% \mathrm{O}_{2}\right)$ may turn out to be viable for organ preconditioning.

Although hypoxia before transplantation had bad effects on graft survival, culture in a standard oxygen gradient did not show to be detrimental to the grafts. In fact, our results were no better than those of the grafts transplanted without prior immersion in culture. Therefore, further studies of ovarian tissue culture for subsequent transplantation are needed.

\section{Conclusion}

The hypoxic preconditioning in vitro on ovarian tissue prior to transplantation was not beneficial to the graft and worsened their viability, compromising its functionality or delaying the return of this in all parameters analyzed.

\section{Competing interests}

The authors declare that they have no competing interests.

\section{Authors' contributions}

LLD conceived and designed study, performed experiments, interpreted data and wrote the manuscript. ECB and JEK conceived and designed study, corrected the manuscript and participated in substantial contribution to conception and revising it critically for important intellectual content. JSN performed experiments and wrote specific sections of this manuscript. RSS performed experiments and interpreted morphological data. JMS and GARM interpreted data and corrected the manuscript. EFSM designed study and 
participated in revising the manuscript. All authors read and approved the final manuscript.

\section{Authors' information}

Where the work was performed: Laboratory of Structural and Molecular Gynecology (LIM-58)/Department of Obstetrics and Gynecology and Laboratory of Genetics and Molecular Cardiology/Heart Institute (Incor), Faculdade de Medicina da Universidade de São Paulo, São Paulo, Brazil.

\section{Acknowledgements}

This work was supported by São Paulo Research Foundation (FAPESP - Process numbers: 2010/17897-5 and 2012/09469-9). Pio XI St, 1500. Alto da Lapa. São Paulo/SP-Brazil. Postal Code: 05468-901.

\section{Author details}

'Gynecology Division, Department of Obstetrics and Gynecology, Laboratory of Structural and Molecular Gynecology (LIM-58), Faculdade de Medicina da Universidade de São Paulo, São Paulo, Brazil. 'Laboratory of Genetics and Molecular Cardiology, Heart Institute (Incor), Faculdade de Medicina da Universidade de São Paulo, São Paulo, Brazil. ${ }^{3}$ Department of Surgery, Laboratory of Surgical Physiopathology (LIM-62), Faculdade de Medicina da Universidade de São Paulo, São Paulo, Brazil. ${ }^{4}$ Galvão Bueno St, 499. Bloco A. Apto31. Liberdade, São Paulo 01506-000, SP, Brazil.

Received: 20 January 2014 Accepted: 10 March 2014

Published: 20 March 2014

\section{References}

1. Rodriguez-Wallberg KA, Oktay K: Options on fertility preservation in female cancer patients. Cancer Treat Rev 2012, 38(5):354-361.

2. Silber SJ: Ovary cryopreservation and transplantation for fertility preservation. Mol Hum Reprod 2012, 18(2):59-67.

3. Smitz J, Dolmans MM, Donnez J, Fortune JE, Hovatta O, Jewgenow K, Picton HM, Plancha C, Shea LD, Stouffer RL, Telfer EE, Woodruff TK, Zelinski MB: Current achievements and future research directions in ovarian tissue culture, in vitro follicle development and transplantation: implications for fertility preservation. Hum Reprod Update 2010, 16(4):395-414.

4. Dolmans MM, Jadoul P, Gilliaux S, Amorim CA, Luyckx V, Squifflet J, Donnez J, van Langendonckt A: A review of 15 years of ovarian tissue bank activities. J Assist Reprod Genet 2013, 30(3):305-314.

5. Grynberg M, Poulain M, Sebag-Peyrelevade S, Le Parco S, Fanchin R, Frydman N: Ovarian tissue and follicle transplantation as an option for fertility preservation. Fertil Steril 2012, 97(6):1260-1268

6. Baird DT, Webb R, Campbell BK, Harkness LM, Gosden RG: Long-term ovarian function in sheep after ovariectomy and transplantation of autografts stored at -196C. Endocrinology 1999, 140(1):462-471.

7. Nisolle M, Casanas-Roux F, Qu J, Motta P, Donnez J: Histologic and ultrastructural evaluation of fresh and frozen-thawed human ovarian xenografts in nude mice. Fertil Steril 2000, 74(1):122-129.

8. Dolmans MM, Martinez-Madrid B, Gadisseux E, Guiot Y, Yuan WY, Torre A, Camboni A, Van Langendonckt A, Donnez J: Short-term transplantation of isolated human ovarian follicles and cortical tissue into nude mice. Reproduction 2007, 134(2):253-262.

9. Schubert B, Canis M, Darcha C, Artonne C, Smitz J, Grizard G: Follicular growth and estradiol follow-up after subcutaneous xenografting of fresh and cryopreserved human ovarian tissue. Fertil Steril 2008, 89(6):1787-1794

10. Nottola SA, Camboni A, Van Langendonckt A, Demylle D, Macchiarelli G, Dolmans MM, Martinez-Madrid B, Correr S, Donnez J: Cryopreservation and xenotransplantation of human ovarian tissue: an ultrastructural study. Fertil Steril 2008, 90(1):23-32.

11. Lan C, Xiao W, Xiao-Hui D, Chun-Yan H, Hong-Ling Y: Tissue culture before transplantation of frozen-thawed human fetal ovarian tissue into immunodeficient mice. Fertil Steril 2010, 93(3):913-919.

12. Damous LL, Silva SM, Simões RS, Morello RJ, Carbonel AP, Simões MJ, Montero EFS: Remote ischemic preconditioning on neovascularization and follicle viability on ovary autotransplantation in rats. Transplant Proc 2008, 40(3):861.

13. Damous LL, Silva SM, Lopes RA, Sakano CR, Simões MJ, Montero EF: Study on the vaginal smear of rats submitted to autologous ovarian transplant: impact of remote ischemic preconditioning. Acta Cir Bras 2009, 24(5):387-392.

14. Zhao J, Li L, Pei Z, Li C, Wei H, Zhang B, Peng Y, Wang Y, Tao Y, Huang R: Peroxisome proliferator activated receptor (PPAR)- $\hat{I}^{3}$ co-activator $1-\hat{I} \pm$ and hypoxia induced factor-1 $1 \hat{ \pm} \pm$ mediate neuro- and vascular protection by hypoxic preconditioning in vitro. Brain Res 2012, 1447:1-8.

15. Stubbs SL, Hsiao ST, Peshavariya HM, Lim SY, Dusting GJ, Dilley RJ: Hypoxic preconditioning enhances survival of human adipose-derived stem cells and conditions endothelial cells in vitro. Stem Cells Dev 2012, 21(11):1887-1896.

16. Marcondes FK, Bianchi FK, Tanno AP: Determination of the estrous cycle phases of rats: some helpful considerations. Braz J Biol 2002, 62(4A):609-614.

17. David A, Dolmans MM, Langendonckt AV, Donnez J, Amorim CA: Immunohistochemical localization of growth factors after cryopreservation and 3 weeks' xenotransplantation of human ovarian tissue. Fertil Steril 2011, 95:1241-1246.

18. Junqueira LC, Carneiro J: Histologia básica. 11ath edition. Rio de Janeiro: Guanabara Koogan; 2008

19. Aerts JMJ, Martinez-Madrid B, Leroy JLMR, Van Aelst S, Bols PEJ: Xenotransplantation by injection of a suspension of isolated preantral ovarian follicles and stroma cells under the kidney capsule of nude mice. Fertil Steril 2010, 94:708-714.

20. Callejo J, Vilaseca S, Ordi J, Cabré S, Lailla JM, Balasch J: Heterotopic ovarian transplantation without vascular pedicle in syngeneic Lewis rats: long-term evaluation of effects on ovarian structure and function. Fertil Steril 2002, 77(2):396-402.

21. Yang H, Lee HH, Lee HC, Ko DS, Kim SS: Assessment of vascular endothelial growth factor expression and apoptosis in the ovarian graft: can exogenous gonadotropin promote angiogenesis after ovarian transplantation? Fertil Steril 2008, 90(4 Suppl):1550-1558.

22. Donnez J, Dolmans MM, Demylle D, Jadoul P, Pirard C, Squifflet J, Martinez-Madrid B, van Langendonckt A: Livebirth after orthotopic transplantation of cryopreserved ovarian tissue. Lancet 2004, 364(9443):1405-1410.

23. Lieberman B: Function of ovarian tissue after long-term storage. Reprod Biomed Online 2012, 25(2):96-97.

24. Labied S, Delforge Y, Munaut C, Blacher S, Colige A, Delcombel R, Henry L, Fransolet M, Jouan C, d'Hauterive SP, Noel A, Nisolle M, Foidart J-M: Isoform 111 of vascular endothelial growth factor (VEGF111) improves angiogenesis of ovarian tissue xenotransplantation. Transplantation 2013, 95(3):426-433.

25. Zhou B, Zhang PJ, Tian T, Jin C, Li Y, Feng M, Liu XY, Jie L, Tao LD: Role of vascular endothelial growth factor in protection of intrahepatic cholangiocytes mediated by hypoxic preconditioning after live transplantation in rats. Transplant Proc 2010, 42(7):2457-2462.

26. Yu X, Lu C, Liu H, Rao S, Cai J, Liu S, Kriegel AJ, Greene AS, Liang M, Ding X: Hypoxic preconditioning with cobalt of bone marrow mesenchymal stem cells improves cell migration and enhances therapy for treatment of ischemic acute kidney injury. PLoS One 2013, 8(5):e62703.

27. Tang YL, Zhu W, Cheng M, Chen L, Zhang J, Sun T, Kishore R, Philips MI, Losordo DW, Qin G: Hypoxic preconditioning enhances the benefit of cardiac progenitor cell therapy for treatment of myocardial infarction by inducing CXCR4 expression. Circ Res 2009, 104(10):1209-1216.

28. Das $R$, Jahr $H$, van Osch GJ, Farrell E: The role of hypoxia in bone marrowderived mesenchymal stem cells: considerations for regenerative medicine approaches. Tissue Eng Part B Rev 2010, 16(2):159-168.

29. Wang J, Chen T, Jiang J, Shi H, Gui C, Luo R, Xie XJ, Xiang MX, Zhang X: Hypoxic preconditioning attenuates hypoxia/reoxygenation-induced apotosis in mesenchymal stem cells. Acta Pharmacol Sin 2008, 29(1):74-82.

30. Bland E, Dréau D, Burg KJ: Overcoming hypoxia to improve tissueengineering approaches to regenerative medicine. J Tissue Eng Regen Med 2012, 7(7):505-514.

31. Hsiao ST, Lokmic Z, Peshavariya H, Abberton KM, Dusting GJ, Lim SY, Dilley RJ: Hypoxic conditioning enhances the angiogenic paracrine activity of human adipose-derived stem cells. Stem Cells Dev 2013, 22(10):1614-1623.

32. Tsai CC, Yew TL, Yang DC, Huang WH, Hung SC: Benefits of hypoxic culture on bone marrow multipotent stromal cells. Am J Blood Res 2012, 2(3):148-159.

33. Yu SP, Wei Z, Wei L: Preconditioning strategy in stem cell transplantation therapy. Trans/ Stroke Res 2013, 4(1):76-88. 
34. Plock J, Frese S, Keogh A, Bisch-Knaden S, Ayuni E, Corazza N, Weikert C, Jakob S, Erni D, Dufour J, Brunner T, Candinas D, Stroka D: Activation of non-ischemic, hypoxia-inducible signalling pathways up-regulate cytoprotective genes in the murine liver. $J$ Hepatol 2007, 47:538-545.

35. Merino JJ, Roncero C, Oset-Gasque MJ, Naddaf A, González MP: Antioxidant and protective mechanisms against hypoxia and hypoglycaemia in cortical neurons in vitro. Int J Mol Sci 2014, 15:2475-2493.

36. Wang J, Hong Z, Zeng C, Yu Q, Wang H: NADPH oxidase 4 promotes cardiac microvascular angiogenesis after hypoxia/reoxygenation in vitro. Free Rad Biol Med 2014, 69:278-288,

37. Zhang Z, Li W, Sun D, Zhao L, Zhang R, Wang Y, Zhou X, Wang H, Cao F: Toll-like receptor 4 signaling in dysfunction of cardiac microvascular endothelial cells under hypoxia/reoxygenation. Inflammation Res 2011, 60:37-45.

doi:10.1186/1757-2215-7-34

Cite this article as: Damous et al.: Females transplanted with ovaries subjected to hypoxic preconditioning show impair of ovarian function. Journal of Ovarian Research 2014 7:34.

\section{Submit your next manuscript to BioMed Central and take full advantage of:}

- Convenient online submission

- Thorough peer review

- No space constraints or color figure charges

- Immediate publication on acceptance

- Inclusion in PubMed, CAS, Scopus and Google Scholar

- Research which is freely available for redistribution 